\title{
Characterization and Design of the FutureGen 2.0 Carbon Storage Site
}

Tyler Gilmore $^{1}$, Alain Bonneville ${ }^{1}$, Charlotte Sullivan ${ }^{1}$, Mark Kelley ${ }^{2}$, Delphine Appriou ${ }^{1}$, Vince Vermeul $^{1}$, Signe White ${ }^{1}$, Fred Zhang ${ }^{1}$, Bruce Bjornstad ${ }^{1}$, Francois Cornet ${ }^{3}$, Jacqueline Gerst ${ }^{2}$, Neeraj Gupta $^{2}$, Gretchen Hund ${ }^{1}$, Jake Horner ${ }^{1}$, George Last ${ }^{1}$, Dave Lanigan ${ }^{1}$, Mart Oostrom ${ }^{1}$, Caitlin McNeil ${ }^{2}$, Mark Moody $^{2}$, Mark Rockhold ${ }^{1}$, Mike Elliott ${ }^{1}$, Frank Spane ${ }^{1}$, Chris Strickland ${ }^{1}$, Lucy Swartz ${ }^{5}$, Paul

Thorne $^{1}$, Christopher Brown ${ }^{1}$, Jeffrey Hoffmann ${ }^{4}$, Kenneth Humphreys ${ }^{5}$

${ }^{1}$ Pacific Northwest National Laboratory, Richland, WA 99352, USA

${ }^{2}$ Battelle, Columbus, Ohio, USA

${ }^{3}$ Geostress, Strasbourg, France

${ }^{4}$ National Energy Technology Laboratory, Pittsburgh, PA, USA

${ }^{5}$ FutureGen Industrial Alliance Inc., Washington, DC, USA

Submitted to the International Journal of Greenhouse Gas Control on July 7, 2016

Keywords: $\mathrm{CO}_{2}$ reservoir, carbon sequestration, characterization, FutureGen 


\begin{abstract}
The objective of the FutureGen 2.0 Project was to demonstrate, at the commercial scale, the technical feasibility of implementing carbon capture and storage in a deep saline formation in Illinois, USA. Over approximately 5 years, the FutureGen Industrial Alliance, Inc. (Alliance) conducted a detailed siteselection process and identified a site for carbon sequestration storage in Morgan County, Illinois. A comprehensive geologic and hydrologic characterization of the storage site was conducted and included the collection of seismic data and the drilling and characterization of a stratigraphic borehole.

The characterization data provided critical input for developing a site-specific conceptual model and subsequent numerical modeling simulations. The modeling simulations, coupled with upstream designs of the pipeline and power plant, supported the development of a detailed design that included the injection wells and associated control and monitoring infrastructure. The Alliance used all of these data to develop the required documentation to support the applications for four underground injection control (UIC) permits (one for each proposed well). In August 2014, the U.S. Environmental Protection Agency issued four, first-of-their-kind, Class VI UIC permits for carbon sequestration in the United States to the Alliance. This equated to one permit per planned injection well. The information and data generated under this project have been made publicly available through reports and publications, including this journal and others.
\end{abstract}




\section{Introduction and Project History}

The objective of the FutureGen 2.0 Project was to demonstrate, at the commercial scale, the technical feasibility of implementing carbon capture and storage (CCS) in a deep saline formation in the U.S. state of Illinois. Previous modeling studies of large-scale carbon dioxide $\left(\mathrm{CO}_{2}\right)$ injection within the Illinois Basin demonstrated this basin's promise as a national CCS resource (Birkholzer and Zhou 2009; Birkholzer et al. 2009; Person et al. 2010). In October 2010, the U.S. Department of Energy (DOE) and the FutureGen Industrial Alliance, Inc. (Alliance) ${ }^{1}$ established a cooperative agreement to develop FutureGen 2.0, the first large-scale repowering project designed to use CCS technology. Under a second cooperative agreement, the Alliance planned to upgrade a coal power plant in Meredosia, Illinois, with oxy-combustion and carbon capture technology. The plant was designed to capture approximately 1.1 million metric tons (MMT) of $\mathrm{CO}_{2}$ emissions each year, over a 20-year period (for a total of $22 \mathrm{MMT}$ ), and reduce other emissions to near-zero levels. The captured $\mathrm{CO}_{2}$ was to be transported through a pipeline to a permanent storage site in Morgan County, Illinois, and injected 1,240 m underground into the Mount Simon Sandstone, a deep saline reservoir, through four horizontal injection wells (Error! Reference source not found.).

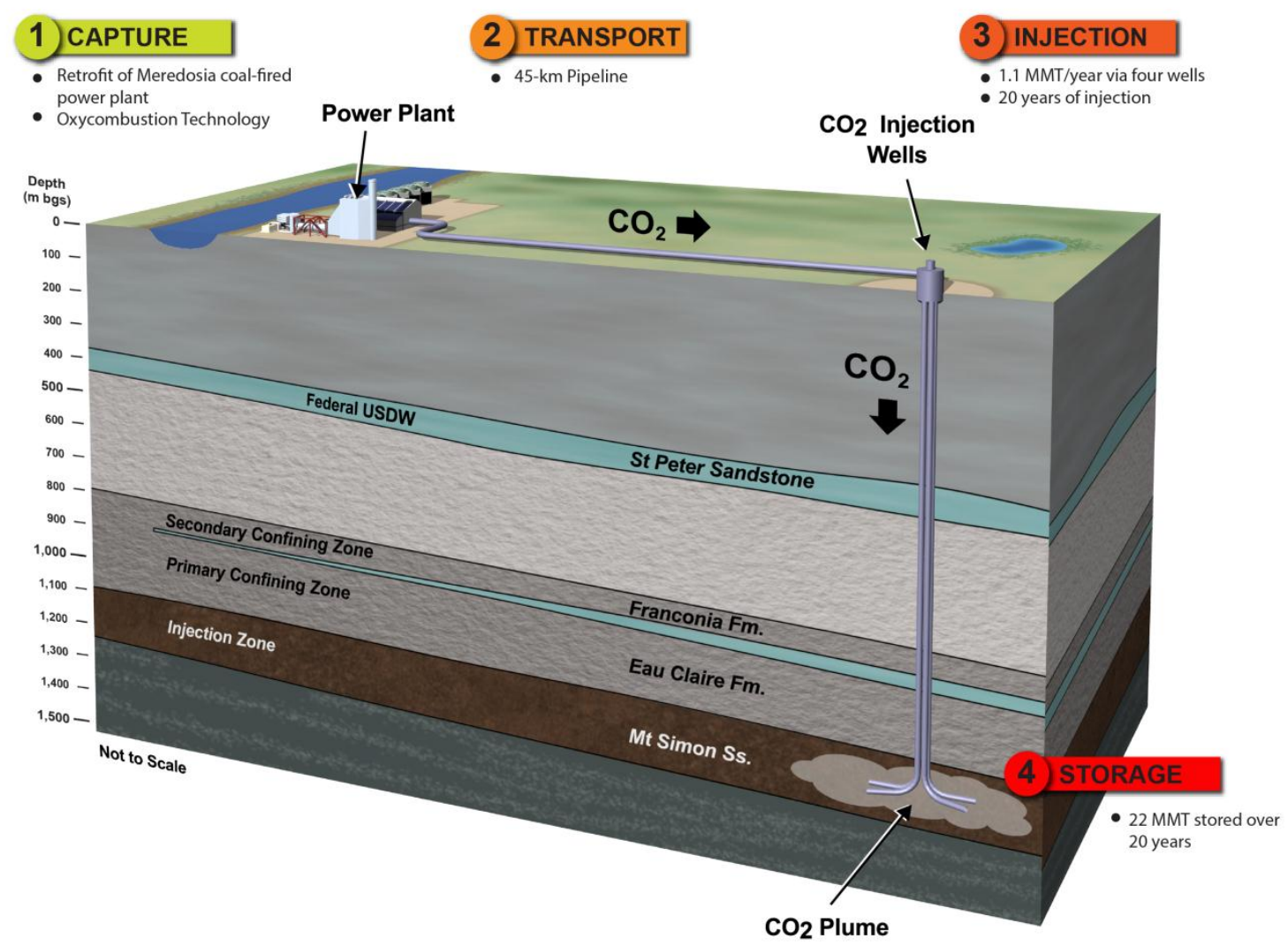

Figure 1. Conceptual Design of the FutureGen 2.0 Project, Illinois, USA

DOE planned to authorize the expenditure of funds for four phases upon successful completion of objectives. The phases included

- Phase I - Project Definition;

\footnotetext{
${ }^{1}$ The Alliance is a non-profit membership organization created to benefit the public interest and the interests of science through research, development, and demonstration of near-zero emissions coal technology.
} 
- Phase II - Permitting and Design;

- Phase III - Construction and Commissioning;

- Phase IV - Operations.

During Phase I, several sites were evaluated and a single final site was selected for the $\mathrm{CO}_{2}$ storage facility. A conceptual design for the storage facilities and cost estimates for the project were prepared. The siting process culminated on February 28, 2011, when the Alliance announced its selection of Morgan County, Illinois, as the preferred location for the FutureGen $2.0 \mathrm{CO}_{2}$ storage site, visitors' center, and research and training facilities. The National Environmental Policy Act process was initiated and a number of subsurface and environmental studies were undertaken. In addition, a stratigraphic (characterization) borehole was drilled at the end of 2011 to evaluate site-specific geology.

Throughout Phase II, which began in February 2013, environmental studies were conducted and completed, frontend engineering design through advanced design was completed, and engineering and construction subcontractors were evaluated and selected (Gilmore et al. 2014). Definitive cost estimates were prepared and numerous permits were obtained for the pipeline and storage project.

On August 29, 2014, the U.S. Environmental Protection Agency (EPA) issued four, first-of-their-kind, Class VI underground injection control (UIC) permits for carbon sequestration in the United States to the Alliance (EPA 2014). A continuous effort by a team of dedicated multidisciplinary experts over a 3-year period was required to produce a permit application that satisfied both the regulatory requirements of the UIC Program and the operational obligations of the project.

On January 28, 2015, DOE directed the Alliance to suspend all FutureGen 2.0 Project activities and decided to close out the cooperative agreement. In February 2016, the Alliance closed out the FutureGen Project. However, during operation of the project, significant advances were made in site characterization, permitting, stakeholder activities, property agreements, and storage site design. This paper highlights some of those activities and provides references for additional information.

\section{Site Selection}

After a rigorous siting process, the Alliance selected Morgan County, Illinois, as its preferred location for the FutureGen 2.0 $\mathrm{CO}_{2}$ storage site (Figure 2) over other alternative sites in the Illinois Basin in Christian and Douglas Counties. Major factors favoring the Morgan County site included the following:

- geologic suitability (based on regional and site-specific data and surface seismic surveys),

- surface and subsurface access (availability of land for the injection wells and ability to obtain subsurface rights to inject $\mathrm{CO}_{2}$ ),

- pipeline distance from the $\mathrm{CO}_{2}$ source, and

- public acceptance (based on a series of stakeholder meetings). 


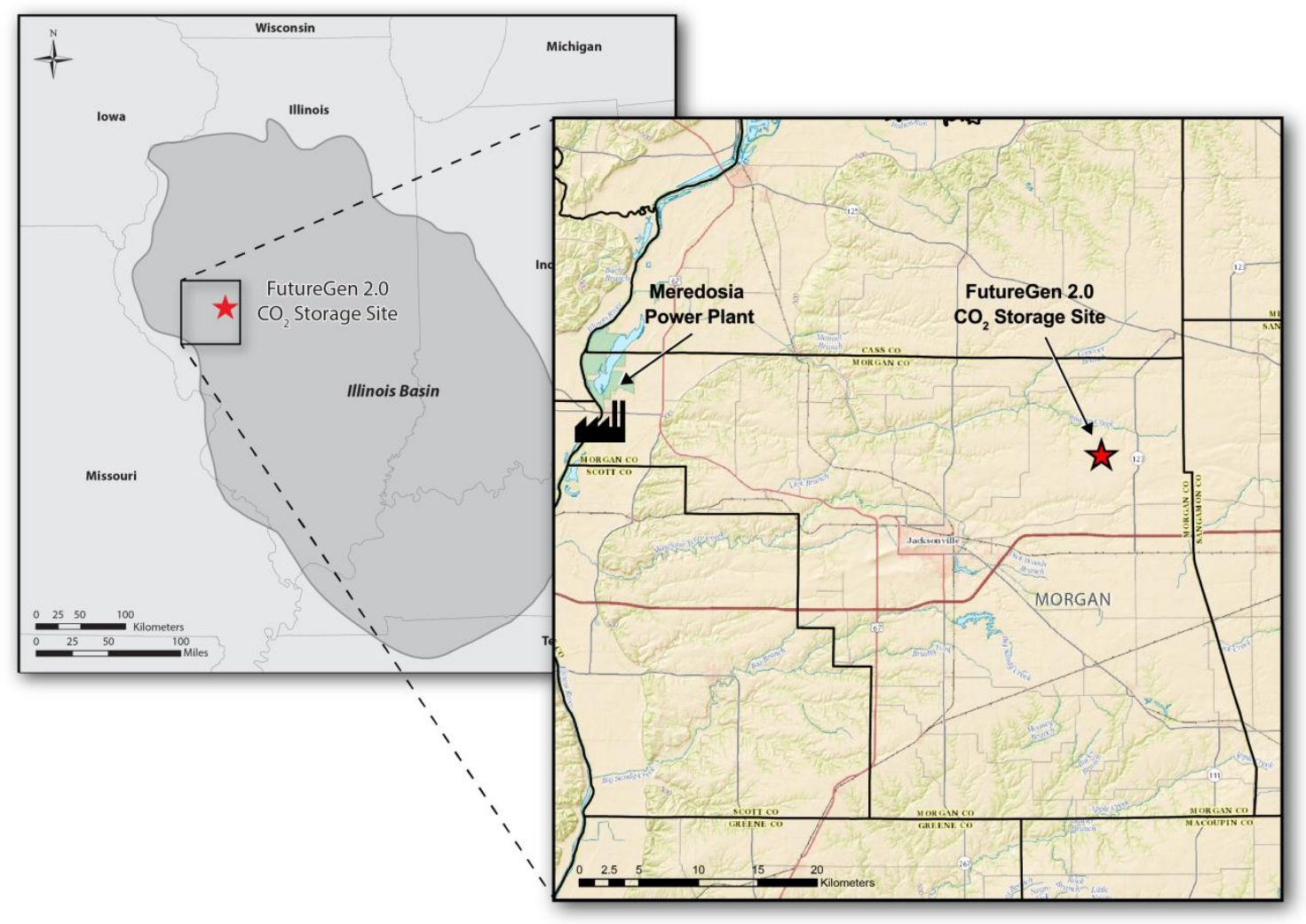

Figure 2. Map Showing the Location of the $\mathrm{CO}_{2}$ Storage Site in the Illinois Basin (left) and in Morgan County (right)

\section{Site Characterization}

A comprehensive characterization program formed the foundation for reducing geologic uncertainty for reservoir capacity and caprock integrity, provided essential parameters for refining the initial reservoir models, and validated the designs for the storage site injection wells and monitoring program. Site characterization progressed from regional to site-specific activities beginning with the review of available regional data to drilling a stratigraphic borehole for detailed characterization. Table 1 references the characterization data collected from the storage site and stratigraphic borehole.

Table 1. Site Characterization Activities

\begin{tabular}{|c|c|c|}
\hline Characterization Activity & Data Use & Reference \\
\hline \multicolumn{3}{|c|}{ FG-1 Shallow Borehole - Total Depth : $70 \mathrm{~m}(230 \mathrm{ft})$ below ground surface } \\
\hline Continuous Coring & $\begin{array}{l}\text { Characterization of Quaternary } \\
\text { sediments and upper portion of the } \\
\text { Pennsylvanian bedrock. }\end{array}$ & $\begin{array}{l}\text { Dey et al. (2012) } \\
\text { Alliance (2015) }\end{array}$ \\
\hline $\begin{array}{l}\text { Geophysical Logging: } \\
\text { Gamma ray, spectral gamma, } \\
\text { resistivity, electromagnetic (EM) } \\
\text { induction, full-wave sonic, and } \\
\text { acoustic imaging }\end{array}$ & $\begin{array}{l}\text { Characterization of Quaternary } \\
\text { sediments and upper portion of the } \\
\text { Pennsylvanian bedrock. }\end{array}$ & Dey et al. (2012) \\
\hline
\end{tabular}


Table 1. (contd)

\begin{tabular}{|c|c|c|}
\hline Characterization Activity & Data Use & Reference \\
\hline $\begin{array}{l}\text { Groundwater Sampling } \\
10 \text { private water wells and shallow } \\
\text { borehole, FG-1 }\end{array}$ & $\begin{array}{l}\text { Analysis of shallow groundwater } \\
\text { quality. }\end{array}$ & Dey et al. (2012) \\
\hline Seismic Survey & $\begin{array}{l}\text { Assessment of the presence of } \\
\text { shallow natural gas. }\end{array}$ & Dey et al. (2012) \\
\hline Electrical Earth Resistivity (EER) & $\begin{array}{l}\text { Assessment of the presence of } \\
\text { aquifer materials at other locations } \\
\text { in the vicinity of FG-1. }\end{array}$ & Dey et al. (2012) \\
\hline \multicolumn{3}{|l|}{ Surface Geophysical Surveys } \\
\hline 2-D seismic surveys & $\begin{array}{l}\text { - Stratigraphic lateral continuity } \\
\text { - Structural analysis. }\end{array}$ & Alliance (2015) \\
\hline Vertical Seismic Profiling & $\begin{array}{l}\text { - Fracture identification } \\
\text { - Identification of stratigraphy } \\
\text { and discontinuities, with } \\
\text { indication of their lateral } \\
\text { continuity or orientation. }\end{array}$ & $\begin{array}{l}\text { Alliance (2015) } \\
\text { Sullivan et al. (2014a) } \\
\text { Sullivan et al. (2014b) }\end{array}$ \\
\hline Gravity Surveys & $\begin{array}{l}\text { - Basin morphology } \\
\text { - Basement topography } \\
\text { - Baseline for future survey to } \\
\text { evaluate variations of density } \\
\text { in the subsurface due to } \mathrm{CO}_{2} \\
\text { injection. }\end{array}$ & Alliance (2015) \\
\hline Geodetic Survey & $\begin{array}{l}\text { - Reference for gravity } \\
\text { measurements } \\
\text { - Baseline for future study of } \\
\text { surface ground deformation. }\end{array}$ & Alliance (2015) \\
\hline \multicolumn{3}{|c|}{ FGA-1 Stratigraphic Borehole Characterization - Total Depth $-1,467$ m below ground surface } \\
\hline $\begin{array}{l}\text { Geophysical Wireline Borehole } \\
\text { Surveys }\end{array}$ & $\begin{array}{l}\text { - Lithology and stratigraphy } \\
\text { characterization } \\
\text { - Identification of fracture zones } \\
\text { - Estimation of formation } \\
\text { permeability, porosity, density } \\
\text { - Location and orientation of } \\
\text { fractures zones } \\
\text { - Mapping of drilling-induced } \\
\text { breakouts and tensile fractures } \\
\text { - Geomechanical properties } \\
\text { evaluation. }\end{array}$ & $\begin{array}{l}\text { Alliance (2015) } \\
\text { Kelley et al. (2012) } \\
\text { Sullivan et al. (2015) } \\
\text { Sullivan et al. (2013) } \\
\text { Spane et al. (2013) } \\
\text { Rockhold et al. (2014) } \\
\text { Bonneville et al. (2013) }\end{array}$ \\
\hline $\begin{array}{l}\text { Intermittent Coring } \\
\text { - Whole core }(62 \mathrm{~m} \text { total; across Eau } \\
\text { Claire/Mount Simon contact and } \\
\text { Mount Simon/PreCambrian } \\
\text { contact) } \\
\text { - Sidewall core ( } 139 \text { cores collected } \\
\text { between } 213 \mathrm{~m} \text { and } 1,462 \mathrm{~m} \\
\text { depths) }\end{array}$ & $\begin{array}{l}\text { Determination of critical formation } \\
\text { parameters needed to support the } \\
\text { development of a site-specific } \\
\text { conceptual model based on: } \\
\text { - routine petrophysical property } \\
\text { analysis (porosity, } \\
\text { permeability, grain density) } \\
\text { - petrographic analysis (thin } \\
\text { section description and general } \\
\text { core description) } \\
\text { - a series of special core } \\
\text { analyses including } \\
\text { geomechanical property } \\
\text { analysis (hydraulic fracture }\end{array}$ & $\begin{array}{l}\text { Alliance (2015) } \\
\text { Kelley et al. (2012) } \\
\text { Spane et al. (2013) } \\
\text { Bonneville et al. (2013) }\end{array}$ \\
\hline
\end{tabular}


Table 1. (contd)

\begin{tabular}{|c|c|c|}
\hline Characterization Activity & Data Use & Reference \\
\hline & $\begin{array}{l}\text { design, triaxial compressive } \\
\text { strength, acoustic velocities, } \\
\text { and uniaxial pore volume } \\
\text { compressibility) multiphase } \\
\text { fluid flow properties (steady- } \\
\text { state gas-brine relative } \\
\text { permeability, measurements } \\
\text { for threshold entry pressure, } \\
\text { and imbibition), formation } \\
\text { resistivity factor, and high- } \\
\text { pressure mercury injection. }\end{array}$ & \\
\hline Hydrologic field testing & $\begin{array}{l}\text { - Provide detailed hydraulic } \\
\text { property information for the } \\
\text { Mount Simon reservoir } \\
\text { - Determine in situ hydro- } \\
\text { chemical and isotopic } \\
\text { characteristics of formation } \\
\text { fluid within the Mount Simon } \\
\text { Sandstone and the St. Peter } \\
\text { Sandstone (lowermost } \\
\text { underground source of } \\
\text { drinking water [USDW]) } \\
\text { - Establish the existing static } \\
\text { pressure/depth profile for the } \\
\text { site. }\end{array}$ & $\begin{array}{l}\text { Alliance (2015) } \\
\text { Kelley et al. (2012) } \\
\text { Spane et al. (2013) }\end{array}$ \\
\hline In situ Stress Characterization & $\begin{array}{l}\text { Determination of state-of-stress in } \\
\text { the injection and underlying } \\
\text { crystalline basement based on a } \\
\text { combination of hydraulic fracture } \\
\text { tests and hydraulic tests on pre- } \\
\text { existing fractures performed within } \\
\text { the open-borehole section of the } \\
\text { stratigraphic borehole. }\end{array}$ & $\begin{array}{l}\text { Alliance (2015) } \\
\text { Cornet (2014) }\end{array}$ \\
\hline
\end{tabular}

\section{Stratigraphic Borehole}

A stratigraphic borehole was drilled in 2011 to increase site-specific knowledge of the geology, namely to confirm that the site had a reservoir with sufficient porosity and permeability to store at least 22 MMT of $\mathrm{CO}_{2}$, a caprock to prevent migration of the stored $\mathrm{CO}_{2}$ out of the reservoir, and sufficient geologic isolation from the lowest most potential source of drinking water. The borehole also provided data on the structural geology at the site and the rock, fluid, and geomechanical properties of the reservoir.

The borehole was drilled to a depth of 1,471 m below ground surface, thereby capturing the entire stratigraphic sequence to the Precambrian crystalline basement rocks (Figure 3). Extensive characterization was conducted in the borehole to generate site-specific information about geologic, hydrogeologic, and biogeochemical conditions. Whole cores and sidewall cores were collected throughout the borehole with excellent whole core recovery across both the contact between the Eau Claire Formation (Fm.) — considered the caprock - and the Mount Simon Sandstone and the contact between the Mount Simon Sandstone and the Precambrian crystalline basement made of metarhyolite (Alliance 2015). These cores were sent to the DOE National Energy Technology Laboratory at the conclusion of the project. 


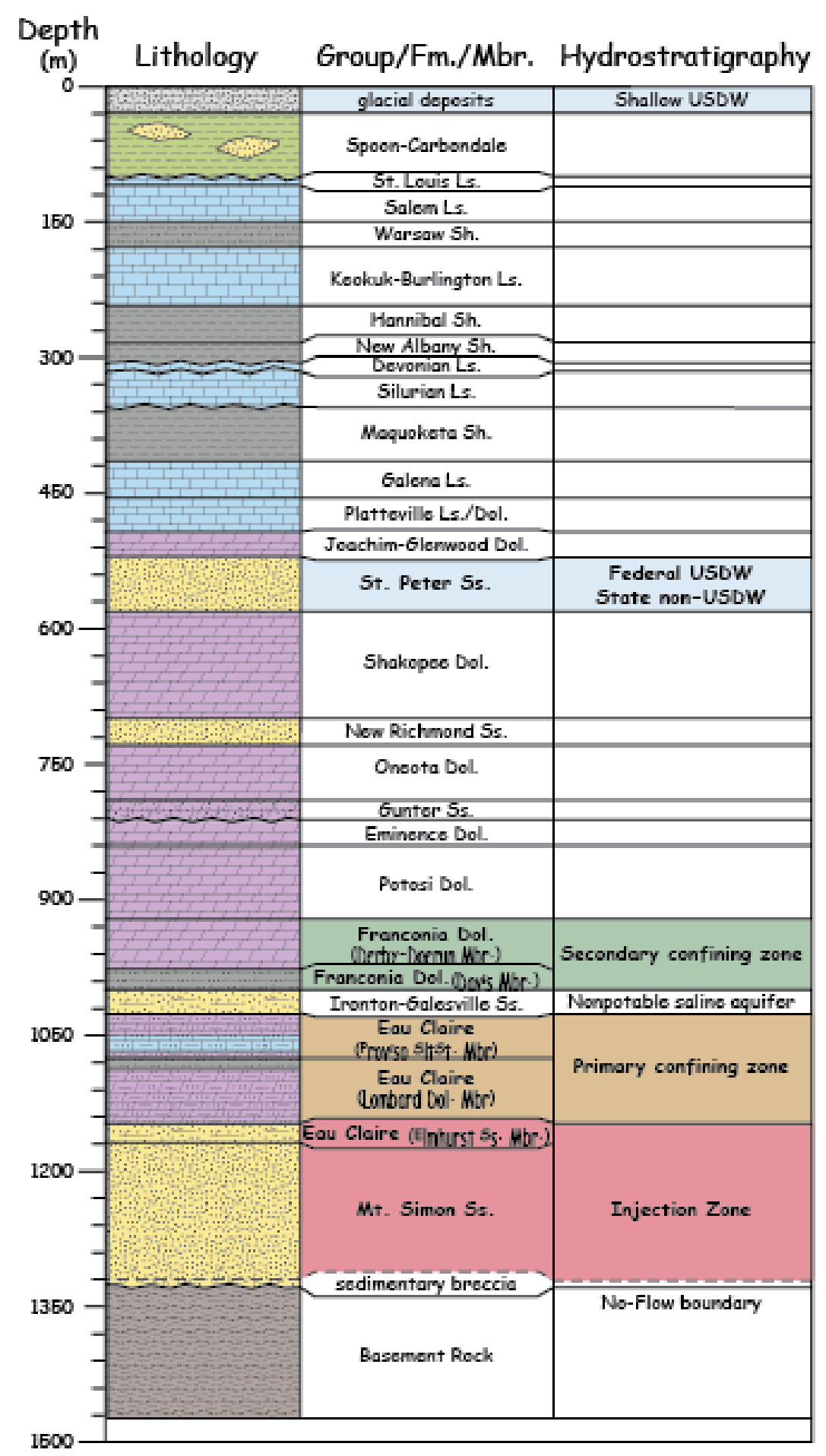

Figure 3. Stratigraphy and Proposed Injection and Confining Zones at the FutureGen $2.0 \mathrm{CO}_{2} \mathrm{Storage}$ Site $(\mathrm{Fm} .=$ formation; $\mathrm{Mbr} .=$ member; $\mathrm{Ss}=$ Sandstone; Dol=Dolomite; $\mathrm{Sh}=$ Shale; Ls=Limestone).

By further revealing the characteristics of the proposed injection zone and confining zones, this borehole enabled the project to move from a generalized understanding of the geology of the region to an 
understanding of the site-specific geology to support UIC permitting and to design the injection and monitoring infrastructure for the $\mathrm{CO}_{2}$ storage site.

The borehole was to be completed as a Mount Simon Sandstone monitoring well in anticipation of the site being developed into a storage site. However, given the DOE's decision to discontinue the FutureGen 2.0 project, the borehole was plugged in May 2015 in accordance with Illinois Department of Natural Resources requirements. The reader should consult the complete borehole characterization report (Kelley et al. 2012) for more detailed information, including work performed, schedule, data collection methods, and data interpretation.

\section{Injection Zone Properties}

The upper Mount Simon Sandstone and the lowest most Elmhurst sandstone member (Mbr.) of the Eau Claire Fm. form the target reservoir for the injection of $\mathrm{CO}_{2}$ and have a cumulative thickness of $172 \mathrm{~m}$ at the stratigraphic borehole (Figure 3). Regionally, the Mount Simon Sandstone has a proven injection zone capacity, based on a number of natural-gas storage facilities across the Illinois Basin (Buschbach and Bond 1974; Morse and Leetaru 2005) and data from the Archer Daniels Midland carbon sequestration site in Macon County, Illinois (Leetaru and McBride 2009). Regional wireline log correlations and core/cuttings descriptions indicate that the Elmhurst Mbr., which represents a widespread marine transgression, is remarkably similar in thickness (16 to $23 \mathrm{~m}$ ) and character from Morgan County to the Manlove natural-gas storage field in Champaign County (central Illinois), where it serves as a natural-gas storage reservoir (Morse and Leetaru 2005).

Figure 4 displays the data collected including geophysical logs and laboratory test results from sidewall and whole core samples. The proposed injection interval (i.e., the location of the horizontal wells' injection laterals) is highlighted on the geophysical log panels.

\subsection{Mount Simon Sandstone}

The Mount Simon Sandstone represents a transgressive marine sequence ranging from a coarse-grained arkosic (feldspar-bearing) quartz-rich sandstone at the base with a generally fining upward sequence to a relatively clean marine sandstone near the top of the formation. The best reservoir zones were identified near the top of the sequence.

The lower Mount Simon Sandstone interval at the stratigraphic borehole appears to be in more poorly sorted sandstones with a marked increase in sand-sized feldspar, lithic, and meta-rhyolite fragments. Reservoir-quality fluvial quartz arenites in the upper Mount Simon Sandstone encountered in the stratigraphic borehole display eolian influence with mature mineralogy and textures, and minor quartz and hematite cement; feldspar grains are absent. Mount Simon Sandstone depositional environments and lithologies were assumed to be laterally continuous over the proposed storage site.

\subsection{Elmhurst Member}

Regionally, the Elmhurst Mbr. sandstones are porous, permeable, and in hydrologic communication with the Mount Simon Sandstone (Buschbach and Bond 1974; Hanson 1960; Hunt 2004; Morse and Leetaru 2005). Site-specific data on the Elmhurst Mbr. show lithologies are dominated by quartz-rich sandstones, siltstones, and silty mudstones, and are interpreted as being deposited within a transgressive tidedominated shallow marine environment. The Elmhurst Mbr. transitions upward into a marine setting in the Lombard Mbr. represented by interbedded, silts, shales, and limestones with lesser occurrences of sandstone. 


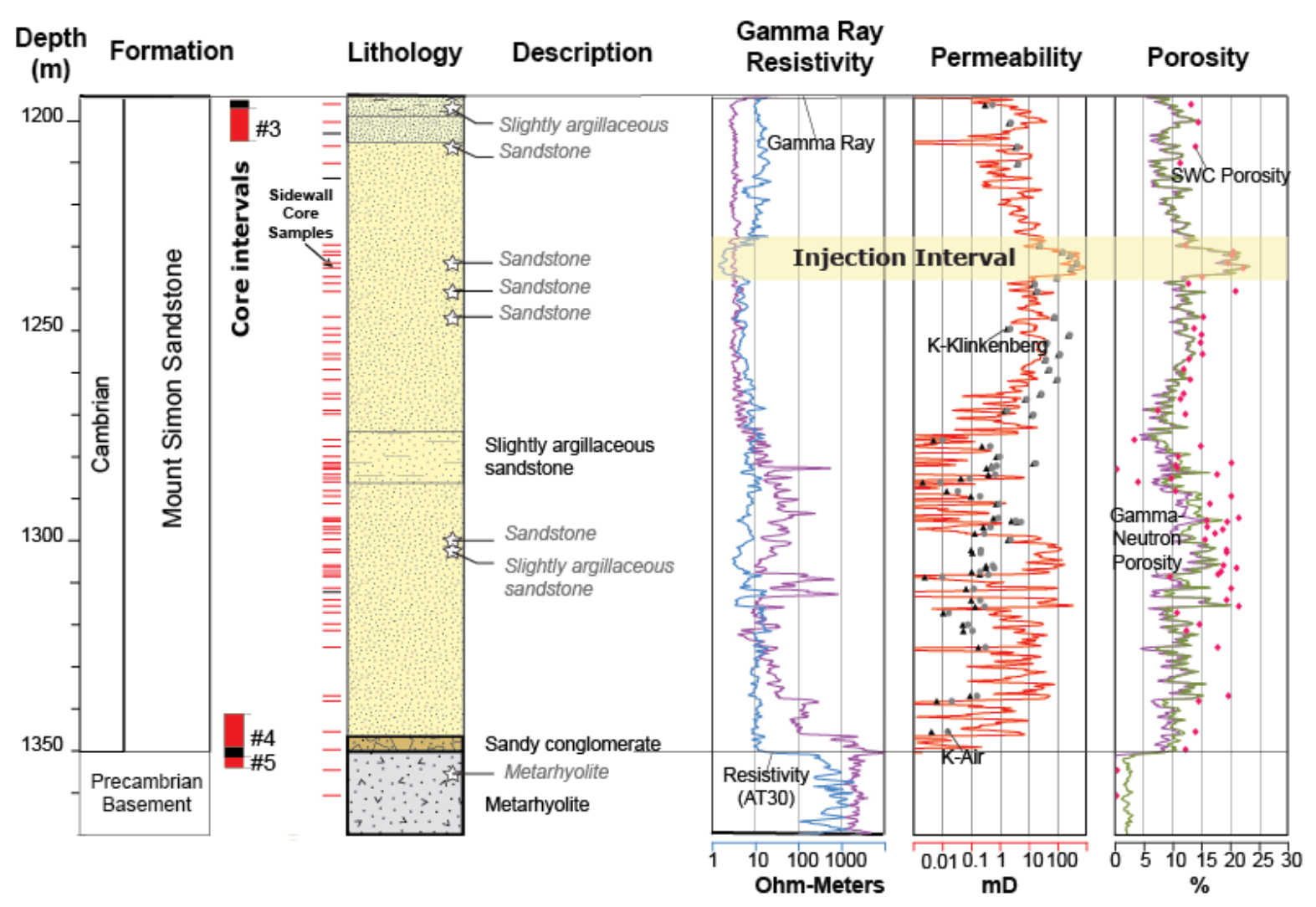

Figure 4. Mount Simon Sandstone Injection Zone Mineralogy, Wireline Log Characterization, and Hydrologic Units. Cored intervals are indicated with red bars; rotary sidewall core and coreplug locations are indicated to the left of the lithology panel. Standard gamma ray and resistivity curves are shown in the second panel; ELAN ${ }^{2}$-calculated permeability (red curve) is in the third panel, along with two different lab measurements of permeability for each rotary sidewall core. Neutron- and density-crossplot porosity are shown in the fourth panel, along with lab-measured porosity for core plugs and rotary sidewall cores.

\section{Primary Confining Zone: Eau Claire Proviso and Lombard Members}

The Proviso and subjacent Lombard Mbrs. of the Eau Claire Fm. form the 126 m thick primary confining zone for the proposed FutureGen $2.0 \mathrm{CO}_{2}$ storage site (Figure 3). They form an effective confining layer at 38 natural-gas storage reservoirs in Illinois (Buschbach and Bond 1974; Morse and Leetaru 2005). Regionally, the Lombard Mbr. of the Eau Claire Fm. consists of glauconitic and sandy dolomite interbedded with mudstones and shale; the shale content increases to the south and sand content increases to the west and north (Willman et al. 1975). The Lombard Mbr. is overlain by the Proviso Mbr., which is characterized by limestone, dolomite, sandy siltstone, and shale beds. The Lombard and Proviso Mbrs. are continuous across the region and major changes are not expected in thickness, lithology, and associated petrophysical and geomechanical properties across the FutureGen $2.0 \mathrm{CO}_{2}$ storage site.

Wireline and core-based lithology, porosity, and permeability for the primary confining zone are shown in Figure 5. The computed lithology track illustrates the upward decrease in sand content in the Lombard

\footnotetext{
${ }^{2}$ ELAN is a registered trademark of Schlumberger, Limited
} 
Mbr. and accompanying decrease in permeability. The permeabilities of the rotary sidewall cores from the Proviso Mbr. range from 0.000005 to $1 \mathrm{mD}$.

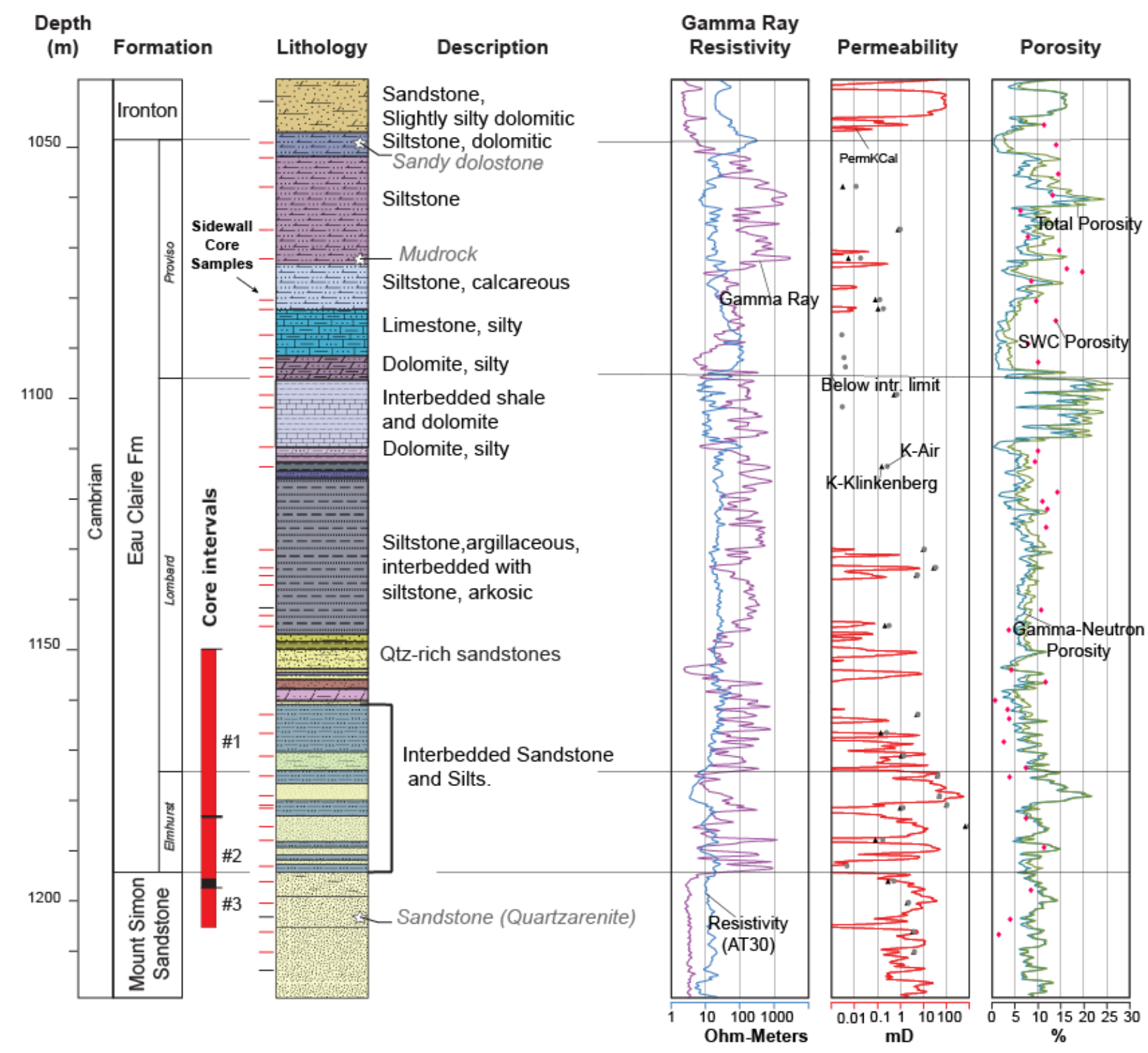

Figure 5. Primary Confining Zone in the Stratigraphic Borehole. Lithology and Selected Rock Properties of the Eau Claire Fm. (see Figure 4 for additional explanations).

\section{Secondary Confining Zone: Franconia and Davis Formations}

The combined $74 \mathrm{~m}$ interval of the carbonate Franconia and Davis Fms. forms a secondary confining zone for the Mount Simon and Elmhurst injection zones (Figure 3). The Franconia Fm. lithology is dominated by microcrystalline dolomite. The underlying Davis Fm. consists of low-permeability, microcrystalline dolomite, argillaceous (shaley), sandy dolomite, and dolomitic siltstones.

\section{Aquifers and Underground Sources of Drinking Water}

The Safe Drinking Water Act established the requirement and provisions for the carbon sequestration UIC permits. Therefore, it was important to identify all possible sources of drinking water at the proposed 
storage site. In Morgan County, the primary source of domestic and agricultural water-supply wells are shallow wells $(<30 \mathrm{~m})$ completed in glacially derived Quaternary sediments that overlie Pennsylvanian bedrock. Four aquifers have been identified below the surficial aquifer (Figure 3). From shallowest (youngest) to deepest (oldest) these are the Ordovician St. Peter Sandstone, the New Richmond Sandstone, and the Cambrian Ironton-Galesville Sandstone, and the Elmhurst Mbr./Mount Simon Sandstone interval. Of the four major lower-bedrock aquifers only the Ordovician St. Peter Sandstone has been considered for future water-supply use (Kolata and Nimz 2010). Based on a water sample collected at the stratigraphic borehole, the St. Peter yielded laboratory-measured total dissolved solids (TDS) of $3,400 \mathrm{mg} / \mathrm{L}$, which is below the federal regulatory upper limit of $10,000 \mathrm{mg} / \mathrm{L}$ for drinking water aquifers. None of the bedrock aquifers below the St. Peter sandstone has been used for water supply within or near Morgan County because of elevated salinities and their depth of occurrence. The Mount Simon Sandstone contains a highly saline aquifer with estimated TDS of approximately 47,500 ppm. This high level of TDS exceeds drinking water standards.

\section{In Situ Stress Characterization}

Numerous aspects of the design and operational activities of the FutureGen $2.0 \mathrm{CO}_{2}$ storage site are dependent on the geomechanical properties of the targeted reservoir zone, as well as on the overlying confining zone and the underlying crystalline Precambrian basement. The geomechanical properties provide estimates for the formation fracture gradient (pressure at which the formation will fracture). The EPA UIC Class VI regulations set the maximum injection pressure, which must not exceed 90 percent of the measured fracture gradient.

Geomechanical testing was conducted in the open-borehole section of the FutureGen 2.0 stratigraphic borehole in the reservoir and basement rocks in November and December 2013. The field testing program included a combination of hydraulic fracturing tests and hydraulic tests on pre-existing fractures conducted to determine the state-of-stress at the FutureGen $2.0 \mathrm{CO}_{2}$ storage site (i.e., determination of magnitude and directional attributes of the three principal stresses) (Cornet, 2014).

Results from the field geomechanical characterization program indicate that one of the principal stress directions is aligned with the vertical direction throughout the characterization depth investigated (i.e., between $1256 \mathrm{~m}$ and $1419 \mathrm{~m}$ below ground surface). The maximum horizontal principal stress direction within the Mount Simon Sandstone is oriented N $51 \pm 3^{\circ} \mathrm{E}$, based on a comparison between pre- and posttest electrical borehole wall imaging logs. Planned horizontal injection wells oriented parallel to this direction within the Mount Simon would be less susceptible to borehole instability during well construction. Within the underlying crystalline basement formation, images of pre-existing and newly created hydraulic fractures exhibited more complexity and indicated a small rotational azimuth aspect in comparison to the overlying Mount Simon. The observed complex basement fracture system was again consistent with a principal stress direction being vertical, but a maximum horizontal principal stress direction value $\mathrm{N} 65^{\circ} \mathrm{E} \pm 18^{\circ}$ was indicated (uncertainty for the $99 \%$ confidence level). The maximum horizontal principal stress directional attributes were in general agreement with previously cited regional maximum horizontal stress directions ( $48 \pm 30^{\circ} \mathrm{E}$ ) reported by Haimson and Doe (1983), which were obtained for the crystalline basement rock in northern Illinois at similar test-interval depths and using similar borehole characterization test methods.

Two measurements of the minimum horizontal stress component were obtained for the Mount Simon Sandstone, namely 22.3 MPa at 1,267 m and 19.3 MPa at 1,291 m. The three test interval measurements between 1,407 and 1,378 m, conducted in the Precambrian crystalline basement, are consistent with a local linear increase with depth for the minimum horizontal stress component as given by the following relationship: 


$$
\sigma_{\mathrm{h}}=26.5+0.0212(\mathrm{z}-1,378)
$$

where $\sigma_{\mathrm{h}}$ is the minimum horizontal stress in $\mathrm{MPa}$ and $\mathrm{z}$ is the depth in $\mathrm{m}$.

The maximum horizontal stress magnitude, $\sigma_{\mathrm{H}}$, in the Mount Simon Sandstone and in the crystalline basement rock, is less constrained and based solely on initial fracture breakdown pressure characteristics. The maximum horizontal principal stress magnitudes for both formations, however, were consistently greater than those computed for the vertical stress component $\left(\sigma_{\mathrm{h}}<\sigma_{\mathrm{v}}<\sigma_{\mathrm{H}}\right)$, which corresponds to a strike-slip tectonic regime.

To prevent development of instabilities (i.e., borehole deformation, fracturing, etc.) because of imposed high pore pressures, the injection pressure must remain smaller than the minimum principal stress conditions. Based on the results for $\sigma_{\mathrm{h}}$, and using an assumed $90 \%$ conservative weighting factor, limiting the Mount Simon reservoir pressure buildup to $\leq 4.86 \mathrm{MPa}$ ( $705 \mathrm{psi}$ ) above static reservoir conditions during injection would likely prevent hydraulic fracturing within the reservoir or induce significant seismic events within the crystalline basement.

From a borehole stability/stress-analysis perspective, the optimum direction for drilling horizontal wells is in the $\mathrm{N} 51^{\circ}$ E direction. The absence of observed breakouts during the drilling of the vertical stratigraphic borehole, however, indicates that the sandstone strength is sufficient to prevent failure of vertical boreholes. Given that vertical boreholes produce larger tangential stress magnitudes than horizontal wells, this borehole stability criterion was not considered to be a limiting factor for selecting or limiting the azimuth of horizontal injection wells to a particular direction.

\section{Storage Site Design}

The characterization activities described in the previous sections provided critical input for developing a site-specific conceptual model and subsequent numerical modeling simulations to aid in the design of the storage site. In addition, the upstream designs of the pipeline and power plant were the key elements of the design of the $\mathrm{CO}_{2}$ storage site.

An iterative process was used to test various well configurations. It was determined that the optimum design would use four horizontal injection wells (between 460 and $760 \mathrm{~m}$ long) within the candidate injection zone, in order to minimize the injection pressures required for the given rate of $\mathrm{CO}_{2}$ injection. Collectively, they were designed and oriented to inject effectively $1.1 \mathrm{MMT} / \mathrm{yr}$ of $\mathrm{CO}_{2}$ over 20 years for a total of $22 \mathrm{MMT}$. The overall system was designed for 20 years of operations $\left(\mathrm{CO}_{2}\right.$ transport and storage) followed by 50 years of post-injection monitoring (or until the permitting authority was satisfied that the $\mathrm{CO}_{2}$ plume extent was stable and that no further monitoring was needed). In early 2014, a detailed design, was completed that included plans for the construction of the four injection wells, an associated monitoring well network, above ground support buildings, design drawings, a detailed cost estimate, and a project schedule (Alliance 2014).

\section{Modeling of $\mathrm{CO}_{2}$ Injection and Transport}

The design of the storage site and the basis for the UIC permit both relied heavily on numerical modeling. To identify the resulting plume over the period of injection and beyond, the $\mathrm{STOMP}_{-} \mathrm{CO}_{2}$ simulator (White et al. 2012) was used to model the coupled hydrologic, chemical, thermal processes, and chemical interactions with aqueous fluids and rock minerals. The plume is identified as the volume in which 99 percent of the mass resides (Zhang et al. 2015).

The conceptual model was expanded to a domain size of 160 by $160 \mathrm{~km}$ and was divided into 31 simulation layers. The three-dimensional, boundary-fitted numerical model grid was designed to have 
constant grid spacing with higher resolution in the $5 \times 5 \mathrm{~km}$ area influenced by the $\mathrm{CO}_{2}$ injection, and with increasingly larger grid spacing moving out in all lateral directions toward the domain boundary. The simulations have been used for estimating $\mathrm{CO}_{2}$ injectivity, $\mathrm{CO}_{2}$ plume extent, pressure distribution, thermal impact of the injection, and for the design of $\mathrm{CO}_{2}$ injection operations. They are detailed in several papers by Nguyen et al. (submitted), Oostrom et al. (2016), White et al. (submitted), and Zhang et al. $(2015,2016)$.

\section{Monitoring, Verification, and Accounting Plan}

The primary objectives of the monitoring program were to track the lateral extent of separate phase $\mathrm{CO}_{2}$ within the injection zone, characterize any geochemical or geomechanical changes that occur within the injection zone, confirm a lack of migration through the overlying caprock, and verify that there are no negative environmental impacts. The monitoring program was designed to ensure that the shallow underground drinking water aquifer is protected by identifying the potential for any $\mathrm{CO}_{2}$ migration well before any negative impact on the aquifer (located more than $600 \mathrm{~m}$ above the $\mathrm{CO}_{2}$ reservoir) and/or on the surface- or near-surface environment could occur. This plan is presented in detail by Vermeul et al. (2016).

\section{Underground Injection Control Permits}

The Alliance developed the required documentation providing comprehensive construction and operations, testing and monitoring, injection well plugging, and post-injection site care and site closure plans, as well as an emergency and remedial response plan, to protect the USDWs. To ensure that sufficient funds were available to undertake these actions, the Alliance also developed a financial responsibility plan. Applications for the four UIC permits (one for each proposed well) were submitted to the EPA in April 2013 (Alliance 2013).

The EPA issued the four, first-of-their-kind, Class VI UIC permits for carbon sequestration in the United States to the Alliance on August 29, 2014 (EPA 2014). Success throughout the permitting process required continuous effort by a team of dedicated multidisciplinary experts over a 3-year period to produce a permit application that satisfied both the regulatory requirements of the UIC Program and the operational obligations of the project.

\section{Summary}

The Alliance partnered with the DOE on the FutureGen 2.0 Project. The objective of the project was to repower a previously retired coal-fired power plant in Meredosia, Illinois, with oxy-combustion technology. The plant was designed to capture approximately $1.1 \mathrm{MMT}$ of $\mathrm{CO}_{2}$ emissions each year, over a 20-year period and reduce other emissions to near-zero levels. The captured $\mathrm{CO}_{2}$ was to be transported through a pipeline to a permanent storage site in Morgan County, Illinois, and injected 1,200 m underground into a deep saline reservoir within the Mount Simon Sandstone through a network of four horizontal injection wells. On January 28, 2015, DOE directed the Alliance to suspend all activities of the FutureGen 2.0 Project and decided to close out the cooperative agreement.

During the nearly 5-year project that started in 2011, the Alliance conducted a detailed site-selection process and identified a site for a carbon sequestration storage site in Morgan County, Illinois. The storage site was fully characterized including the collection of seismic data as well as the drilling and characterization of a stratigraphic borehole. The data generated were used to design the site and submit applications for underground injection permits. 
Permit applications and supporting documentation were prepared for each of the four proposed injection wells. The applications presented evidence that the injection zone was of sufficient depth, thickness, porosity, and permeability to contain the proposed $22 \mathrm{MMT}_{\text {of }} \mathrm{CO}_{2}$. The injection zone is overlain by the Eau Claire Fm., a thick regional layer of predominantly sandstone that is of sufficient thickness, lateral continuity, and has low enough permeability to serve as the primary confining zone or caprock. No faults or fractures were identified based on geophysical well logs of the stratigraphic borehole and seismic analysis of the site. The storage site also affords a secondary confining zone, the Franconia Fm., for additional protection of USDWs.

The EPA issued the four, first-of-their-kind Class VI UIC permits for carbon sequestration in the United States to the Alliance on August 29, 2014 (EPA 2014).

\section{Acknowledgements}

The FutureGen 2.0 Project was supported by U.S. federal funding from the American Recovery and Reinvestment Act. The program was implemented under Cooperative Agreement DE-FE0001882 between the U.S. Department of Energy and the FutureGen Industrial Alliance, Inc. All the information generated from this project has been made publicly available through reports and publications, including this journal and others. The authors thank an anonymous reviewer for his detailed and constructive comments.

\section{References}

Alliance (FutureGen Industrial Alliance, Inc.). 2013. Class VI Underground Injection Control Permit Applications and Supporting Documentation submitted to the U.S. Environmental Protection Agency on March 15, 2013 and subsequently revised in response to EPA's completeness review on May 13, 2013.

Alliance (FutureGen Industrial Alliance, Inc.). 2014. Subsurface Storage and Monitoring, Verification and Accounting - 90\% Design Report. Unpublished document, FG-02-RPT-0006, 244 pp.

Alliance (FutureGen Industrial Alliance, Inc.). 2015. Pipeline and Regional Carbon Capture Storage Project. Final Scientific and Technical Report. Unpublished document.

Birkholzer, J.T., Zhou, Q. 2009. Basin-scale hydrogeologic impacts of $\mathrm{CO}_{2}$ storage: Capacity and regulatory implications. International Journal of Greenhouse Gas Control, 3, 745-756.

Birkholzer J.T., Zhou, Q. Tsang, C. 2009. Large-scale impact of $\mathrm{CO}_{2}$ storage in deep saline aquifers: A sensitivity study on pressure response in stratified systems. International Journal of Greenhouse Gas Control 3(2):181-194.

Bonneville, A., Gilmore, T, Sullivan, C., Vermeul, V., Kelley, M., White, S., Appriou, D., Bjornstad, B., Gerst, J., Gupta, N., Horner, J., McNeil, C., Moody, M., Rike, W., Spane, F., Thorne, P., Zeller, E., Zhang, F., Hoffmann, J., Humphreys, K. 2013. Evaluating the Suitability for $\mathrm{CO}_{2}$ Storage at the FutureGen 2.0 Site, Morgan County, Illinois, USA. Energy Procedia 37, 6125-6132.

Buschbach, T.C., Bond, D.C. 1974. Underground storage of natural gas in Illinois, 1973. Dept. of Registration and Education, Illinois State Geological Survey, Champaign, Illinois.

Cornet, F. 2014. Results from the In-Situ Stress Characterization Program, Phase 1: Geomechanical Tests Conducted in the FutureGen Stratigraphic Well (FGA\#1). PNWD-4421, Battelle, Pacific Northwest Division, Richland, Washington. 
Dey, W.S., Locke, R.A., Krapac, I.G., Patterson, C.G., Hurry, J.L. 2012. Preliminary Hydrogeologic Investigation of the FutureGen 2.0 Site in Morgan County, Illinois. Illinois State Geological Survey, Prairie Research Institute, University of Illinois at Urbana-Champaign. Open File Series 2012-6.

EPA (U.S. Environmental Protection Agency). 2014. FutureGen UIC Class VI Permit Documents for Wells 1, 2, 3 and 4 (and associated attachments). Documents IL-137-6A-0001/-0002/-0003/-0004 issued on August 29, 2014 (and attachments), EPA Region 5. Available at:

http://www.epa.gov/Region5/water/uic/futuregen/index.htm.

Gilmore, T.J., Bonneville, A., Vermeul, V., Spane, F., Kelley, M.E., Sullivan, C., Hoffmann, J. 2014. Overview of the $\mathrm{CO}_{2}$ Geological Storage Site for the FutureGen Project in Morgan County Illinois, USA. Energy Procedia 63, 6361-6367.

Haimson BC and TW Doe. 1983. "State of Stress, Permeability, and Fractures in the Precambrian Granite of Northern Illinois.” Journal of Geophysical Research 88:7355-7371.

Hanson, G.F. 1960. Summary Statement of Facilities for Underground Storage of Liquid Petroleum Products. University of Wisconsin, Wisconsin Geological and Natural History Survey, Madison, Wisconsin.

Hunt, L.I. 2004. A Petrophysical and Shallow Geophysical Study to Determine Pathways of Gas Migration Within and Above an Underground Gas Storage Field in North-Central Illinois. Illinois State University, Normal, Illinois, p. 57.

Kelley, M., Moody, M.A., Zeller E.R., Rike, W.H., Berelsman, N.A., McNeil, C., Holley, J., Sullivan, C., Appriou, D., Spane, F.A., Horner, J.A., Gilmore, T. 2012. Borehole Completion and Characterization Summary Report for the Stratigraphic Well, Morgan County, Illinois. PNWD-4343, Battelle, Pacific Northwest Division, Richland, Washington.

Kolata, D.R., Nimz, C.K. 2010. Geology of Illinois. Illinois State Geological Survey, Champaign, Illinois.

Leetaru, H.E. McBride, J.H. 2009. Reservoir uncertainty, Precambrian topography, and carbon sequestration in the Mt. Simon Sandstone, Illinois Basin. Environmental Geosciences 16, 235-243.

Morse, D.G., Leetaru, H.E. 2005. Reservoir Characterization and Three-dimensional Models of Mt. Simon Gas Storage Fields in the Illinois Basin in: CD-ROM (Ed.). Illinois State Geological Survey, Champaign, Illinois, p. 72.

Nguyen, B.N., Hou, Z., Stewart, M.L., Murray, C.J., Bonneville, A. (submitted). Thermal Impact of Supercritical $\mathrm{CO}_{2}$ Injection on Geomechanical Response at the FutureGEN 2.0 Site: A Three-dimensional Thermo-geomechanical Approach. International Journal of Greenhouse Gas Control.

Oostrom, M., White, M.D., Porse, S.L., Krevor, S.C.M., Mathias, S. 2016. Comparison of relative permeability-saturation-capillary pressure models for simulation of reservoir $\mathrm{CO}_{2}$ injection. International Journal of Greenhouse Gas Control, 70-85.

Person, M., Banerjee, A., Rupp, J., Medina, C., Lichtner, P., Gable, C., Pawar, R., Celia, M., McIntosh, J., Bense, V. 2010. Assessment of basin-scale hydrologic impacts of $\mathrm{CO}_{2}$ sequestration, Illinois basin. International Journal of Greenhouse Gas Control 4, 840-854. 
Rockhold ,M., Zhang, F., White, S., Bonneville, A., Gilmore, T. 2014. Estimation of Rock Mechanical, Hydraulic, and Thermal Properties Using Wire-Line Log and Core Data from the FutureGen2.0 Site, Well No, 1, Morgan County Illinois: SEG Technical Program Expanded Abstracts, pp. 2585-2589.

Spane, F.A., Sullivan, E.C., Thorne, P.D., Kelley, M.E. 2013. Integration of Selected Wireline Logs, Core Analysis, and Borehole Testing Results for Detailed Reservoir Permeability Characterization: Results from the FutureGen Characterization Borehole. 12th Annual Carbon Capture Utilization \& Sequestration Conference in Pittsburgh, Pennsylvania, May 13-16, 2013; PNNL-SA-92986, Pacific Northwest National Laboratory, Richland, Washington.

Sullivan, E.C., Hardage, B., Strickland, C., Bonneville, A., Gilmore, T. 2014a. Application of Threecomponent VSP Technology at Seismically Difficult Sites: An Example from the FutureGen2.0 Site, Morgan County, Illinois, USA: GHGT 12. Energy Procedia 63, 5051-5062.

Sullivan, E.C., Horner, J.A., Appriou, D., Brown, C.F., Gilmore, T.J. 2015. Continental Sequence Stratigraphy of the Mount Simon at the FutureGen 2.0 Site in Morgan County, Illinois. Poster presentation at the 14th Annual Carbon Capture and Utilization Conference, April 28-May1, 2015, Pittsburgh, Pennsylvania.

Sullivan, E.C., Horner, J.A., Gilmore, T.J., Appriou, D. 2013. Lithofacies and Depositional Environments of the Mount Simon and Lower Eau Claire Formations in the FutureGen2.0 Characterization Well in Morgan County, Illinois. 12th Annual Conference on Carbon Capture Utilization \& Sequestration, Pittsburg, Pennsylvania; PNNL-SA-92987, Pacific Northwest National Laboratory, Richland, Washington.

Sullivan, E.C., Strickland, C.E., Bonneville, A., Gilmore, T.J. 2014b. Results of Three Component VSP Acquisition at the FutureGen 2.0 Site, Morgan County, Illinois. 13th Annual Carbon Capture, Utilization \& Storage Conference (CCUS), Pittsburg, Pennsylvania; PNWD-SA-10282, Pacific Northwest National Laboratory, Richland, Washington.

Vermeul, V.R., Amonette, J.E., Strickland, C.E., Williams, M.D., Bonneville, A. 2016. An Overview of the Monitoring Program Design for the FutureGen $2.0 \mathrm{CO}_{2}$ Storage Site, International Journal of Greenhouse Gas Control 51, 6, 193-206.

White, M.D., Bacon, D.H., McGrail, B.P., Watson, D.J., White, S.K., Zhang, Z.F. 2012. STOMP Subsurface Transport Over Multiple Phases: STOMP-CO2 and STOMP-CO2e Guide: Version 1.0. PNNL-21268, Pacific Northwest National Laboratory, Richland, Washington.

White, S.K., Zhang, F., Oostrom, M. (submitted). Modeling plume behavior and pressure buildup resulting from $\mathrm{CO}_{2}$ injection in a stratified reservoir through multiple lateral injection wells. International Journal of Greenhouse Gas Control.

Willman, H., Atherton, A., Buschbach, T., Collinson, C., Frey, J., Hopkins, M., Lineback, J., Simon, J. 1975. Handbook of Illinois stratigraphy. Illinois State Geological Survey, Champaign, Illinois.

Zhang, F., Oostrom, M., White, M. 2016. Relative Permeability for Multiphase Flow for Oven-Dry to Full Saturation Conditions. International Journal of Greenhouse Gas Control, 49, 259-266.

Zhang, F., White, S.K., White, M.D. 2015. Delineating the horizontal plume extent and $\mathrm{CO}_{2}$ distribution at geologic sequestration sites. International Journal of Greenhouse Gas Control, 43, 141-148. 